\title{
Monitoring Antibodies to Mycoplasma hyopneumoniae in Sow Colostrum - a Tool to Document Freedom of Infection
}

\author{
By E. Rautiainen ${ }^{1}$, V. Tuovinen ${ }^{2}$ and K. Levonen ${ }^{3}$
}

\begin{abstract}
* 1 National Veterinary and Food Research Institute, Regional Laboratory in Seinäjoki, and Department of Clinical Veterinary Sciences, Faculty of Veterinary Medicine, University of Helsinki, and ${ }^{2}$ LSO Foods Ltd., Turku, Finland ${ }^{\mathrm{a}},{ }^{3}$ Schneverdingen, Germany.
\end{abstract}

\begin{abstract}
Rautiainen E, Tuovinen V, Levonen K: Monitoring antibodies to Mycoplasma hyopneumoniae in sow colostrum - a tool to document freedom of infection. Acta vet. scand. 2000, 41, 213-225 - In a survey in Finland in 1995, 14919 colostral whey samples from 530 farrowing herds were analysed by a monoclonal blocking-ELISA to detect antibodies to Mycoplasma hyopneumoniae (M. hyopneumoniae). Antibodies were detected in $274(1.8 \%)$ samples and in 42 herds $(7.9 \%)$. The median prevalence of sows with antibodies in seropositive herds was $28.2 \%$ (range, $2.7-100 \%$ ). According to clinical and pathological follow-up in finishing herds in 1996, all of the farrowing herds which were seronegative in 1995 , were truly non-infected with $M$. hyopneumoniae. In acutely infected herds, samples collected earlier than $2 \mathrm{~h}$ after farrowing were 3 times more likely to contain antibodies than samples collected 2-12 $\mathrm{h}$ after farrowing (odds ratio, 3.0; 95\% CI, 1.4-6.6). Repeated freezing or spoilage of the colostrum samples did not cause biologically relevant problems for the ELISA. Antibodies to M. hyopneumoniae were shown to persist up to 3 years in some sows. As a conclusion, colostrum samples were very sensitive samples for the screening of herds for $M$. hyopneumoniae infection and possibly also for a regular surveillance.
\end{abstract}

monoclonal; blocking-ELISA; survey; sensitivity; specificity; sample size; sampling scheme; persistence; antibodies; health; control; programme.

\section{Introduction}

Mycoplasma hyopneumoniae (M. hyopneumoniae) is the causative agent of swine enzootic pneumonia, one of the most common and economically important diseases occurring in swine (Ross 1999). Demonstration of specific antibodies in colostrum, as a control method for M. hyopneumoniae, was introduced by Zimmermann et al. (1986) and applied by Levonen (1994a). The use of sow colostrum instead of serum for antibody detection has several advantages: 1 . Antibodies to M. hyopneumoniae, detected by the enzyme-linked immunosorbent assay (ELISA), may persist at least one year (Armstrong et al. 1983, Bereiter et al. 1990), which makes sows a suitable target group for serological surveys; 2 . Of the immunoglobulin content of colostrum, $90 \%$ is of serum origin (Bourne \& Curtis 1973); 3. At the time of farrowing, colostrum contains a higher concentration of antibodies than serum (Eberli 1987, Yagihashi et al. 1993, Sørensen et al. 1993, Morris et al. 1994). This is due to the fact that the antibody level in serum of sows is related to the stage of pregnancy and continuously decreases during the month prior to parturition (Wallgren et al. 1998). Further, the IgA

\footnotetext{
* Corresponding author

a Present address: Lihakunta, P.O. Box 147, FIN-70101

Kuopio, Finland
} 
in colostrum $(10 \%-15 \%$ of the total colostral immunoglobulins) is for the most part produced in the mammary gland (Bourne \& Curtis 1973); 4. Finally, colostrum samples are easily collected by the herd managers and the samples can be stored frozen in the herds for later usage. In addition, colostrum sampling is less stressful for the animals than blood sampling.

In this paper, we report the large scale usage of colostrum samples in Finland as a part of 2 health control programmes which aimed to eliminate $M$. hyopneumoniae from elite breeding herds and conventional sow herds, respectively. During 1995, there were 161000 sows in Finland (Anon. 1997a) and the production was concentrated to the western and the southwestern parts of the country. The mean number of sows per herd was 35 . Two thirds of the fattening pigs were raised in specialized fattening herds. Such herds typically had 200-300 pigs located in one unit and practised all-in/all-out management systems. The growers (Yorkshire $x$ Landrace) generally arrived at the weight of approximately $25 \mathrm{~kg}$ and originated from 15-20 different farrowing herds.

Swine enzootic pneumonia with secondary infections was the most common cause of death in the fattening herds during 1990 and in-feed medications were commonly used to prevent acute outbreaks of disease during the fattening period (Rautiainen et al. 1991). The prevalence of $M$. hyopneumoniae in sow herds was $30 \%$ in the Western Finland (Rautiainen 1998) and 8\% in the Southwestern Finland (Tuovinen et al. 1994). Antibodies to Actinobacillus pleuropneumoniae (serotype 2) were common even in the elite breeding herds, but the infections were almost entirely subclinical (Levonen et al. 1994b). Porcine reproductive and respiratory syndrome (PRRS) has never been reported in Finland (Anon. 1998).

The objective of this study was to determine, whether farrowing herds can be documented free of $M$. hyopneumoniae infection by monitoring antibodies in sow colostrum. Respect was paid to the size of the herds when the sample sizes required were defined. In addition, the significance of the age of the sampled sows, as well as the time of sampling in comparison to farrowing were validated. Further, the robustness of the sampling strategy was tested by deliberately handling samples in improper ways. Finally, the persistence of antibodies to $M$. hyopneumoniae following eradication. was studied in one herd.

\section{Materials and methods}

The health control programme for the elite breeding herds

According to the national health control programme (Anon. 1997b), the elite breeding herds in Finland are declared free of $M$. hyopneumoniae and of the following other pathogens: Toxigenic Pasteurella multocida, Serpulina hyodysenteriae, Clostridium perfringens type C, Sarcoptes scabiei var. suis and all serotypes of salmonella. In addition, a clinical freedom of Actinobacillus pleuropneumoniae (serotype 2) is claimed. The herd monitoring of $M$. hyopneumoniae is based on clinical veterinary inspections every third month and on colostrum serology every sixth month. Further, clinical inspections and individual slaughter inspections of pigs delivered to the fenotype testing stations are performed. Annually, 1\%-2\% of the breeding herds get infected with $M$. hyopneumoniae (Rautiainen et al. 1996) and are excluded from the programme. The number of the herds participating in the national health control programme in 1995 was 183 and most of the herds were established breeding herds.

\section{The LSO-2000 quality chain}

The LSO-2000 quality chain, started in 1994 by HK Foods Ltd., Turku, includes a health control programme for conventional sow herds in the 
Southwestern Finland (Tuovinen \& Heinonen 1997). The health monitoring is similar to that of the breeding herds and same diseases are monitored excluding the clostridial diarrhea of piglets. The sow herds are classified into a health class or a standard class. The growers of the health class herds are transported to separate all-in/all-out finishing herds without mixing them with standard growers. Their health status is followed clinically and by lung examination at slaughter. The health class herds $(n=347$ during 1995) are paid more for their growers than the standard class herds.

\section{Colostrum samples}

Colostrum samples without additives were collected by the herd managers into $10 \mathrm{ml}$ plastic tubes. The samples were collected during farrowing or as soon as possible after it. The managers were asked to include the following information of the sows with each sample: the identity number of the sow, the date of farrowing, the parity number, the time of the first piglet born and the time of the sampling. The samples were stored in home freezers $\left(-18^{\circ} \mathrm{C}\right)$. Batches of 15 to 30 samples, wrapped in paper and packed in card board boxes, were sent to the laboratory. The majority of the samples arrived at the laboratory within $24 \mathrm{~h}$ after dispatch. In 1995, the total number of samples was 14919 originating from 530 herds. In small herds, the number of samples per herd corresponded to the number of sows. From large herds, not more than 30 samples were expected. With this sample size it was possible to find at least one sample with antibodies with $95 \%$ confidence in any size of herds, if the prevalence of samples with antibodies was at least 10\% (Cannon \& Roe 1982).

\section{Detection of antibodies to M. hyopneumoniae}

Before the analysis, all samples were centrifuged at $5500 \times \mathrm{g}$ (Heraeus Sepatech, Mega- fuge 1.0, Germany) for $15 \mathrm{~min}$ in $5 \mathrm{ml}$ plastic tubes (Sarstedt ${ }^{\circledR}$, Nümbrecht, Germany), and the fatty layer was removed by a vacuum connected pipette. The colostral whey was analysed by a monoclonal blocking-ELISA ( $\mathrm{Myco}$ plasma hyopneumoniae ELISA ${ }^{\circledR}$, DAKO, Glostrup, Denmark) in single wells to detect antibodies to $M$. hyopneumoniae. ELISA results were expressed as percentages of blocking of the monoclonal antibody used in the assay. A sample with a blocking-percentage over $50 \%$ at $492 \mathrm{~nm}$ wave length was classified as having antibodies (positive). All other samples were classified as negative. At the cut-off value of $50 \%$, the sensitivity and the specificity of the ELISA (with $95 \%$ confidence intervals) have been reported to be $100 \%$ (98\% to $100 \%)$ and $100 \%$ (93\% to $100 \%$ ), respectively (Sørensen et al. 1997).

\section{Classification of herds}

A herd was classified as non-infected during 1995 if it was serologically negative, free from clinical respiratory symptoms according to regular veterinary inspections and feed-back from the corresponding finishing herds (testing stations) and slaughterhouse did not indicate $M$. hyopneumoniae infection during 1996. In addition, more colostrum samples were analysed during 1996 to ascertain the seronegativity of the herds.

A herd was classified as truly infected with $M$. hyopneumoniae, if antibodies were detected in 3 or more samples. Since the true specificity of the test used in this study was $99 \%$ in individual serum samples (Sørensen et al. 1992, Sørensen et al. 1993, Sørensen et al. 1997) and the number of samples tested per herd was at most 30 , the probability of getting 3 or more positive samples in a non-infected herd was only $0.3 \%$ as calculated according to the uppertail binomial probability distribution (Casella \& Berger 1990). 
If antibodies were detected in less than 3 colostrum samples in a herd, additional clinical inspections were made by the local veterinarian. If respiratory symptoms indicating $M$. hyopneumoniae infection were detected, the herd was classified as possibly infected and could not join the health control programme.

If no respiratory symptoms were detected, blood samples were collected to detect serum antibodies to $M$. hyopneumoniae in growing pigs. Animals under 10 weeks of age were not sampled, because antibodies rarely are found in that age group of pigs (Wallgren et al. 1998). If no antibodies were detected, herds were classified as non-infected provided that no signs of $M$. hyopneumoniae were reported during the finishing period or at slaughter during the subsequent year. In addition, more colostrum samples were analysed.

\section{Influence of parity number and time of sampling}

The influences of the parity number of a sow and of the time of sampling (in hours) on the test results were analysed with the samples of the truly infected herds.

\section{The effect of fat and contaminants}

In order to analyse any major influence of fat and contaminants of colostrum samples on the test results, 22 colostrum samples were chosen. To prevent bias caused by herds or by the age of the sows, every sample was from a different herd and the samples were evenly chosen from first, second, third and fourth parity sows.

Each sample was divided into subsamples $1 \mathrm{~A}$ and $1 \mathrm{~B}$. The samples $1 \mathrm{~A}$ were centrifuged 5500 $\mathrm{x} g$ for $30 \mathrm{~min}$ at room temperature. The samples $1 \mathrm{~B}$ were centrifuged $4000 \mathrm{xg}$ for $60 \mathrm{~min}$ at constant $+20^{\circ} \mathrm{C}$ temperature (Hettich, Rotanta/RPC, Tuttlingen, Germany). The fat content (\%) was estimated using a standard line measurer (Vis, Inox, $0.05 \mathrm{~mm}$ ) and the fatty layer was removed. Both samples were analysed for antibodies to $M$. hyopneumoniae in dublicate wells on the same microtiter plate.

\section{The effect of repeated freezing and spoilage}

The influence of repeated freezing of colostrum samples on the test results was analysed in 44 samples. Twenty-two of the samples originated from 3 herds with no antibodies to M. hyopneumoniae. The other 22 samples originated from 6 herds with antibodies to $M$. hyopneumoniae in 3 or more samples. All samples were divided into subsamples $2 \mathrm{~A}$ and $2 \mathrm{~B}$, and then frozen at $-18^{\circ} \mathrm{C}$. The samples $2 \mathrm{~B}$ were thawed in room temperature (for $1.5 \mathrm{~h}$ ) and frozen again 10 times. Then, both $2 \mathrm{~A}$ and $2 \mathrm{~B}$ were thawed and centrifuged $5500 \mathrm{x}$ g for $30 \mathrm{~min}$. The fat- $\%$ was measured, the fat was removed and the samples were analysed for antibodies to M. hyopneumoniae in dublicate wells on the same microtiter plates.

In order to analyse the influence of spoilage of colostrum samples on the test results, the samples 2B were finally left in room temperature for $65 \mathrm{~h}$ (2.5 days). Thereafter, the samples, now named $2 \mathrm{C}$, and the samples $2 \mathrm{~A}$ were centrifuged $4000 \mathrm{x}$ g for $60 \mathrm{~min}$ at constant $+20^{\circ} \mathrm{C}$ temperature. Both samples were analysed parallel as described above.

\section{Persistence of antibodies following an eradication programme}

An acute $M$. hyopneumoniae infection was diagnosed clinically, pathologically, and serologically in one elite breeding herd (herd X) with 35 sows during October 1994. An eradication programme was introduced in June 1995 using a method of partial depopulation combined with medication (Zimmermann et al. 1989). In order to follow the serological status of the sows after the eradication programme, a total of 211 colostrum samples were collected at regular intervals between May 1996 and October 
1998 for detection of antibodies to M. hyopneumoniae. Thirty-nine of these samples originated from 18 breeding sows born before the eradication programme. From 7 of these sows there were samples from 2 successive farrowings. The remaining 172 samples originated from 105 replacement gilts and sows born after the eradication programme.

\section{The statistical analyses}

The sensitivity of the ELISA on herd level was defined as the proportion of herds infected with M. hyopneumoniae in 1995 that had one or more colostrum samples with antibodies. The specificity was defined as the proportion of herds not infected with $M$. hyopneumoniae in 1995 that did not have antibodies in any of the colostrum samples. The $95 \%$ confidence intervals (CI) for binomial data were calculated according to Casella \& Berger (1990). The blocking-values of different groups of sows were compared using the 2-tailed Mann-Whitney U-test.

The associations between seropositivity and parity number of the sow, seropositivity and the time of sampling in relation to farrowing as well as seropositivity and complete vs. incomplete information of parity number and time of sampling were analysed using chi-square tests. For further analyses, the parity number of the sow and the time of sampling were used as dichotomous variables. The herds were divided into 2 groups based on the median prevalence of sows with antibodies. Multiple logistic regression was used to assess the strength of association between the seropositivity and the parity number of the sow and also the time of sampling in the full data and in the data stratified by the 2 groups of herds. Interactions were evaluated with previously selected variables forced in the model.

The difference between the blocking-values of the subsamples $1 \mathrm{~A}$ and $1 \mathrm{~B}$ was tested with a paired t-test to analyze whether the mean difference of the pairs was different from zero. The correlation between the difference and the fat$\%$ was tested with Pearson correlation. Also differences between the subsamples $2 \mathrm{~A}$, when compared with subsamples $2 \mathrm{~B}$ and $2 \mathrm{C}$, respectively, as well as the correlation of the differences obtained with the fat-\% were calculated using these analysing methods. Based on $95 \%$ confidence level $\left(Z_{\alpha}=1.96\right), 80 \%$ power $\left(Z_{\beta}=\right.$ $-0.84)$ and $5 \%$-units expected standard deviation (s) in any of the differences $\left(X_{1}-X_{2}\right)$, a 4\%units difference would be detected with the sample size of $22(\mathrm{n})$, and a $3 \%$-units difference with a sample size of 44 based on the following equation: $\mathrm{n}=2\left[\left(\mathrm{Z}_{\alpha}-\mathrm{Z}_{\beta}\right) \mathrm{s} /\left(\mathrm{X}_{1}-\mathrm{X}_{2}\right)\right]^{2}$ (Martin et al. 1987).

The difference between the blocking-percentages of the samples of the 2 successive farrowings in the elite breeding herd $\mathrm{X}$ was tested with a paired t-test.

The statistical package used in the analyses was Statistix ${ }^{\circledR} 4.1$ (Analytical Software, Tallahassee).

\section{Results}

Detection of antibodies to M. hyopneumoniae Antibodies to $M$. hyopneumoniae were detected in $274(1.8 \%)$ samples and in 42 herds (7.9\%). The median prevalence of sows with antibodies in seropositive herds was $28.2 \%$ (range, $2.7 \%$ $100 \%$ ). In the remaining herds (488 herds), no antibodies were detected.

By the definitions, 31 herds were truly infected with $M$. hyopneumoniae (4 elite breeding herds, 27 LSO-2000 herds). In 11 herds with a maximum of 2 positive sows additional inspections were made. Respiratory symptoms were recorded in 3 of the herds, and these herds were excluded from the study (Table 1). The remaining eight herds were concluded non-infected by the additional tests (Table 1). In these herds, the mean blocking-percentages (B) were higher 
Table 1. The herds with one or 2 colostrum samples with antibodies to Mycoplasma hyopneumoniae detected in blocking-ELISA in a survey of 530 herds in Finland in 1995. The herds $(n=31)$ with 3 or more samples with antibodies were classified as truly infected (not shown in the table).

\begin{tabular}{|c|c|c|c|c|c|c|c|c|}
\hline \multirow[b]{2}{*}{$\begin{array}{l}\text { Herd } \\
\text { number }\end{array}$} & \multirow[b]{2}{*}{$\begin{array}{l}\text { No. of } \\
\text { colostrum } \\
\text { samples }\end{array}$} & \multirow[b]{2}{*}{$\begin{array}{c}\text { No. of } \\
\text { samples } \\
\text { with } \\
\text { antibodies } \\
(\%)\end{array}$} & \multirow[b]{2}{*}{$\begin{array}{c}\text { Mean } \\
\text { blocking-\% } \\
\text { of the samples } \\
\text { with } \\
\text { antibodies }\end{array}$} & \multirow[b]{2}{*}{$\begin{array}{l}\text { Respiratory } \\
\text { symptoms } \\
\text { detected }\end{array}$} & \multirow[b]{2}{*}{$\begin{array}{c}\text { No. of } \\
\text { additional } \\
\text { blood } \\
\text { samples (no } \\
\text { antibodies) }\end{array}$} & \multicolumn{2}{|c|}{ Follow-up in 1996} & \multirow[b]{2}{*}{$\begin{array}{c}\text { Classification } \\
\text { of the herds }\end{array}$} \\
\hline & & & & & & $\begin{array}{l}\text { Feed-back from } \\
\text { the finishing } \\
\text { herds } \\
\text { indicating } \\
\text { SEP }\end{array}$ & $\begin{array}{c}\text { No. of } \\
\text { colostrum } \\
\text { samples (no } \\
\text { antibodies) }\end{array}$ & \\
\hline 1 & 37 & $1(2.7)$ & $66.3^{c}$ & no & 14 & no & 42 & \\
\hline 2 & 30 & $1(3.3)$ & 51.9 & no & 10 & no & 30 & \\
\hline 3 & 30 & $1(3.3)$ & 53.4 & no & 10 & no & 30 & non- \\
\hline 4 & 30 & $1(3.3)$ & $59.6^{c}$ & no & 4 & no & 30 & infected \\
\hline 5 & 15 & $1(6.7)$ & 50.1 & no & 10 & no & 30 & herds \\
\hline 6 & 15 & $1(6.7)$ & $58.3^{c}$ & no & 30 & no & 31 & \\
\hline 7 & 10 & $1(10.0)$ & 50.7 & no & 7 & no & 17 & \\
\hline 8 & 20 & $2(10.0)$ & $60.5^{\mathrm{c}}$ & no & & no & 23 & \\
\hline 9 & 15 & $2(13.3)$ & 53.3 & yes & & & & possibly \\
\hline 10 & 15 & $2(13.3)$ & 64.4 & yes & & & & infected \\
\hline 11 & 6 & $2(33.3)$ & 74.9 & yes & & & & herds \\
\hline
\end{tabular}

a The cut-off value for a positive result was $50 \%$.

${ }^{\mathrm{b}} \mathrm{SEP}=$ swine enzootic pneumonia.

c The sows with antibodies not born in the herd.

$(\mathrm{p}=0.02)$ among sows purchased $\left(\mathrm{B}_{492}=61.0 \%\right.$, standard deviation (SD) 3.1\%) than among sows originating from the herds $\left(\mathrm{B}_{492}=51.5 \%\right.$, SD $1.5 \%)$.

In total, $496(488+8)$ herds were tested free from M. hyopneumoniae during 1995 and a majority $(\mathrm{N}=464$ herds, including the 8 herds with false positive reactions) of the herds still joined a health control programme the following year, which enabled a long-term monitoring of these herds. Most herds (462 herds) remained free from $M$. hyopneumoniae, while a $M$. hyopneumoniae infection was diagnosed in 2 of the 464 herds during 1996. On the basis of the clinical and the serological findings of a regular monitoring, it was concluded that these 2 herds experienced a recent infection and not a chronic, earlier non-detected M. hyopneumoniae infection.

From 32 out of 496 herds, neither regular nor clinical serological samples were received in 1996. In 1997, twelve of these herds delivered colostrum samples again and no antibodies were detected.

\section{Sensitivity and specificity}

From the results given above, the sensitivity of the ELISA on herd level was calculated to $100 \%(95 \% \mathrm{CI}, 87 \%-100 \% ; \mathrm{n}=34)$ since all herds shown to be infected with $M$. hyopneumoniae during 1995 were detected in the survey performed that year. The specificity on herd level was $98 \%$ (95\% CI, 97\%-99\%) calculated as the proportion of the herds not infected with $M$. hyopneumoniae $(\mathrm{n}=464)$ that did not have antibodies in any of the colostrum samples in $1995(n=456)$, i.e. $(456 / 464) * 100 \%$.

\section{The effect of the parity number and the time of} sampling

One of the herds (herd no. 13) truly infected with $M$. hyopneumoniae was censored from this analysis. That herd was a large, newly established multi-site farrowing herd and was, thus, 
Table 2a. The crude associations of seropositivity to Mycoplasma hyopneumoniae in colostrum with the age of the sow and with the time of sampling in comparison to farrowing in samples of 30 truly-infected herds according to chi-square tests. The parity number and the time of sampling were known of 610 and 403 samples, respectively.

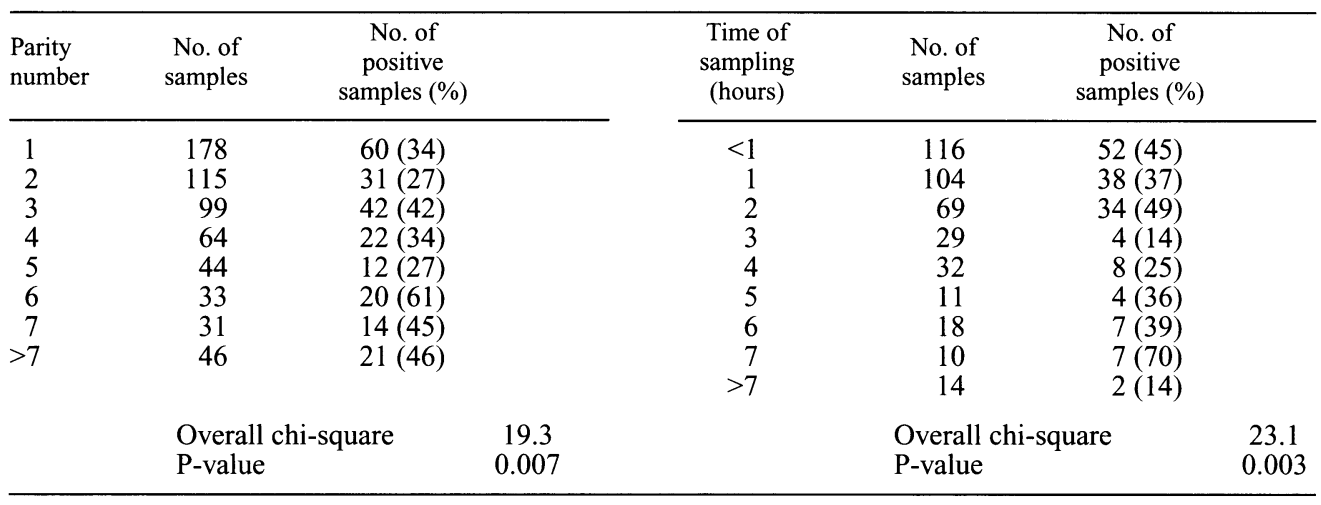

not considered to be a conventional farrowing herd.

From 648 samples collected from 30 infected herds, $230(36 \%)$ contained antibodies to $M$. hyopneumoniae. The parity number was recorded from 610 sows (Table 2a). The mean time from farrowing to sampling was $1.9 \mathrm{~h}$ (me- dian, $1.0 \mathrm{~h}$; range, $0-12.0 \mathrm{~h} ; \mathrm{n}=403$ ) and $99 \%$ of the samples were collected within $8 \mathrm{~h}$ from farrowing. The longest recorded time from farrowing to sampling of a colostrum sample with antibodies was $8.5 \mathrm{~h}$. Both the parity number of the sow and the time of sampling were known for 388 samples, which originated from 28

Table $2 \mathrm{~b}$. The association of seropositivity to Mycoplasma hyopneumoniae in colostrum with the age of the sow and the time of sampling in comparison to farrowing, according to multiple logistic regression analyses in the full data and in the data stratified by the median prevalence ( $36 \%$ ) of sows with antibodies in 28 truly-infected herds.

\begin{tabular}{llrrr}
\hline & & Coefficient & P-value & $\begin{array}{c}\text { Odds ratio } \\
\text { (95\% limits) }\end{array}$ \\
\hline $\begin{array}{llrr}\text { Full data } \\
\text { (no. of samples }\end{array}$ & CONSTANT & -1.037 & $<0.001$ & \\
388) & OLD $^{\mathrm{a}}$ & 0.794 & 0.005 & $2.2(1.3-3.9)$ \\
& SOON $^{\mathrm{b}}$ & 0.619 & 0.012 & $1.9(1.2-3.0)$ \\
High prevalence & CONSTANT & -0.631 & 0.087 & \\
herds (no. of & OLD & 0.118 & 0.769 & $1.1(0.5-2.5)$ \\
samples 161) & SOON & 1.104 & 0.006 & $3.0(1.4-6.6)$ \\
& & & & \\
Low prevalence & CONSTANT & -1.240 & $<0.001$ & $3.3(1.5-7.5)$ \\
herds (no. of & OLD & 1.206 & 0.004 & $1.1(0.6-2.0)$ \\
samples 227) & SOON & 0.056 & 0.864 & \\
\hline
\end{tabular}

a $\mathrm{OLD}=1$ : parity number higher than $5(\mathrm{n}=62) ; \mathrm{OLD}=0$ : parity number lower than or equal to $5(\mathrm{n}=326)$

${ }^{\mathrm{b}} \mathrm{SOON}=1$ : time of sampling shorter than $2.0 \mathrm{~h}(\mathrm{n}=278) ;$ SOON $=0$ : time of sampling 2.0-12.0 $\mathrm{h}(\mathrm{n}=110)$ 
Table 3. The influence of extended centrifugation, repeated freezing and spoiling on the blocking-values of colostrum samples in a monoclonal blocking-ELISA for the detection of antibodies to Mycoplasma hyopneumoniae.

\begin{tabular}{|c|c|c|c|c|c|c|c|}
\hline & \multirow{2}{*}{$\begin{array}{c}\text { No. of } \\
\text { samples }\end{array}$} & \multicolumn{2}{|c|}{ Blocking-\% } & \multicolumn{4}{|c|}{$\begin{array}{l}\text { Difference of the manipulated } \\
\text { and the control samples }\end{array}$} \\
\hline & & median & range & mean & SD & range & p-value ${ }^{d}$ \\
\hline Control: samples 1A & 22 & 23.1 & $9.6-67.1$ & & & & \\
\hline Extended centrifugation ${ }^{\mathrm{a}}$ : samples $1 \mathrm{~B}$ & 22 & 23.8 & $9.5-70.1$ & -2.0 & 5.2 & $-10.1-7.0$ & 0.079 \\
\hline Control: samples 2A & 44 & 38.4 & $0-95.5$ & & & & \\
\hline Repeated freezing ${ }^{\mathrm{b}}$ : samples $2 \mathrm{~B}$ & 44 & 44.5 & $0-95.3$ & 2.2 & 4.7 & $-6.9-13.7$ & 0.004 \\
\hline Control: samples 2A & 42 & 37.8 & $0-95.1$ & & & & \\
\hline Spoiling': samples 2C & 42 & 35.8 & $0-95.1$ & -1.3 & 6.3 & $-17.9-10.9$ & 0.193 \\
\hline
\end{tabular}

a Samples 1B centrifuged $4000 \mathrm{x}$ g for $60 \mathrm{~min}$, samples 1A centrifuged $5500 \mathrm{x}$ g for $30 \mathrm{~min}$.

${ }^{b}$ Samples $2 \mathrm{~B}$ frozen 10 times repeatedly in successive work days.

c Samples 2C same as samples 2B, but left in room temperature for $65 \mathrm{~h}$. Two samples were inadequate for analysis.

d Paired t-test.

herds. The samples with incomplete information were significantly less often seropositive than the samples with complete information ( $p$ $=0.03$ ).

The crude associations between seropositivity and the parity number of the sows, as well as the time of sampling in comparison to farrowing are shown in Table 2a. Seropositivity was associated with the parity number of the sows ( $p=$ 0.007 ), as well as with time of sampling in comparison to farrowing $(p=0.003)$. However, there was no linear dose-response relationship between either of the variables and the seropositivity. Consequently, the time of sampling was converted into a dichotomous variable SOON (1: time $<2.0 \mathrm{~h} ; 0$ : time $\geq 2.0 \mathrm{~h}$ ) and the parity number was converted into a dichotomous variable OLD ( 1 : parity number $>5$; 0 : parity number $\geq 5$ ). According to the median prevalence of sows with antibodies $(36 \%)$, the herds were divided into 2 groups. The associations between the variables were analysed in 3 models (Table 2b) (the non-significant interaction terms were not included). Seropositivity as the dependent variable, the odds ratio was 3.0 (95\% CI, 1.46.6) for samples collected soon after the farrowing $(\mathrm{SOON}=1)$ as compared to samples collected later in herds with a high prevalence of sows with antibodies. The odds ratio was 3.3 (95\% CI, 1.5-7.5) for samples of old sows $(\mathrm{OLD}=1)$ as compared to samples of young sows in herds with a low prevalence of antibodies.

\section{Effect of the extended centrifugation}

The mean fat- $\%$ of the samples was $9.9 \%$ (SD, $4.2 \%$; range, $4.0-23.0 \%$ ). The blocking-percentages between the subsamples $1 \mathrm{~A}$ and $1 \mathrm{~B}$ did not differ significantly (Table 3 ).

Effect of the repeated freezing and the spoilage The mean fat-\% of the samples was $10.8 \%$ (SD, $4.2 \%$; range, $2.2-21.2 \%$ ). The blocking-percentages of the subsamples $2 \mathrm{~B}$ were significantly higher than those of the subsamples $2 \mathrm{~A}$ (Table 3 ). The fat- $\%$ of the samples did not cor- 
Table 4. The detection of colostral antibodies to Mycoplasma hyopneumoniae in blocking-ELISA in 18 sows from an infected herd born before completion of an eradication programme during summer 1995. Antibodies were not detected in 105 replacement gilts and sows born after completion of the eradication programme.

\begin{tabular}{|c|c|c|c|c|c|c|c|}
\hline \multirow{2}{*}{$\begin{array}{l}\text { Sow } \\
\text { number }\end{array}$} & \multirow{2}{*}{$\begin{array}{l}\text { Before the } \\
\text { eradication } \\
\text { programme }\end{array}$} & \multicolumn{6}{|c|}{ Time after effectuating the eradication programme (months) } \\
\hline & & $7-12$ & $13-18$ & $19-24$ & $25-30$ & $31-36$ & $37-42$ \\
\hline 1 & - & - & - & & - & & \\
\hline 2 & - & & & & & + & \\
\hline 3 & + & & + & & & & \\
\hline 4 & + & & + & & & & \\
\hline 5 & - & + & + & & & + & + \\
\hline 6 & - & - & & & & & \\
\hline 7 & - & - & & - & - & & - \\
\hline 8 & + & & & + & + & + & \\
\hline 9 & + & + & + & & & & \\
\hline 10 & - & + & + & + & + & & \\
\hline 11 & - & & + & + & + & & \\
\hline 12 & - & + & + & + & & & \\
\hline 13 & + & + & + & & + & & \\
\hline 14 & & + & & & & & \\
\hline 15 & + & + & & & & & \\
\hline 16 & + & + & & & - & & \\
\hline 17 & - & & & & - & & \\
\hline 18 & - & & & & & & - \\
\hline
\end{tabular}

+ antibodies detected

- antibodies not detected

relate with the difference of the blocking-values $(\mathrm{p}=0.95)$.

The blocking-percentages of the subsamples $2 \mathrm{~A}$ and $2 \mathrm{C}$ did not differ significantly (Table 3 ). Two samples were excluded from the final analysis because of too little colostral whey left.

Persistence of antibodies following an eradication programme

Antibodies to $M$. hyopneumoniae were not detected in any of the 172 samples collected from the 105 replacement gilts and sows born after the eradication programme. According to the health control programme, herd $\mathrm{X}$ was decleared free from M. hyopneumoniae in the beginning of 1996.

Antibodies to $M$. hyopneumoniae were detected in 13 of the 18 breeding sows born before the eradication programme. From 7 of the seropositive sows there were samples from 2 successive farrowings. The mean blocking-values of the former and the latter samples were $78.3 \%$ and $78.2 \%$, respectively $(\mathrm{p}=0.98)$.

Antibodies have been detected in colostrum more than 3 years following the eradication programme (Table 4).

\section{Discussion}

In this study, herds with no antibodies to $M$. hyopneumoniae in colostrum samples were defined as non-infected with M. hyopneumoniae, if they were free from clinical signs of disease during the following 12 months and no signs of infection were observed in the corresponding finishing herds (testing stations) or in the slaughterhouses. This monitoring was regarded 
reliable in detecting an infection if present, because it was continued for a year and carried out in 3 different sites. In addition, mixing of growers from multiple sources is a known risk factor for respiratory diseases if the health status of the source herds differs from each other (Zimmermann et al. 1989, Christensen et al. 1999). Therefore, this monitoring was used as gold standard for evaluation of the sensitivity of the test at the herd level. It turned out that the ELISA detected all infected herds in 1995, since all of the serologically negative herds were defined as truly non-infected. This corresponded to a herd level sensitivity of $100 \%$ (CI, $87 \%-100 \%)$, which made the test very suitable for use as a screening test.

Antibodies to M. hyopneumoniae were detected in 42 herds. Herds, that were classified as truly or possibly infected herds were excluded from the health control programmes. The numbers of the excluded herds in Southwestern Finland (27/347) and breeding herds (4/183) corresponded well to the numbers observed earlier (Tuovinen et al. 1994, Rautiainen et al. 1996).

None of the herds with less than $10 \%$ prevalence of positive samples was found truly infected with M. hyopneumoniae (Table 1). Thus, based on a minimum of $10 \%$ prevalence of positive samples in truly infected herds, a minimum of 19-25 samples would have been enough to declare herds with 30-100 sows free from $M$. hyopneumoniae infection with $95 \%$ confidence (Cannon \& Roe 1982). The decreasing of the number of samples analysed per large herds (with 30-100 sows) would, in addition, increase the herd-level specificity by about $0.3 \%$ units (using the equations of Martin et al. 1992).

Early sampling $(<2.0 \mathrm{~h}$ after the start of farrowing compared to 2.0 to $12.0 \mathrm{~h}$ ) increased the probability of detecting colostral antibodies to M. hyopneumoniae in infected herds (Table $2 b$ ). This was in accordance with earlier findings
(Klobasa et al. 1986, Klobasa \& Butler 1987). However, when the data was stratified by the status of infection of the herds, early sampling increased the number of positive samples only in herds with a high prevalence of positive samples, i.e. in recently infected herds. Early sampling could, therefore, be a useful tool for increasing the sensitivity in surveillance programmes, which aim to detect an infection as early as possible. Testing high parity sows (parity number $>5$ ) was also a tool to increase the number of positive samples, but only in herds with a low prevalence of positive samples, i.e. in herds with a low pathogen load with respect to sows. Earlier reports are conflicting. Klobasa $\&$ Butler (1987) reported a tendency for $\geq 5$ th parity sows to have more antibodies in colostrum than younger sows, while a gradual decrease in the prevalence of positive samples was observed with increasing parity number in another study (Yagihashi et al. 1993). Obviously, farm to farm variation exists and the parity number of sows ought not be criterion for testing in a survey study.

The parity number, still, as well as the history of the sows is important in some circumstances. In our study, antibodies to $M$. hyopneumoniae were found up to 3 years after the infection was eradicated. Hence, the serological status of sows present in herds after eradication programmes may not represent the current health status of such herds. A similar situation was faced in the survey of the study. In 4 out of the 8 false positive herds, the seropositive sows were purchased animals. The mean blockingpercentage of the purchased animals was much higher than that of the seropositive sows in the other 4 herds $(61 \%$ and $52 \%$, respectively; $p=$ 0.02). Therefore, it is possible that the ELISA did correctly identify true seropositive purchased sows which, however, had not transmitted the infection into the new herds. If that was the case, the herds were in fact not antibody 
"false-positive" herds.

When colostrum samples were exposed to extreme conditions a significant but biologically irrelevant increase in the blocking-percentages was noted in the repeatedly frozen samples. That increase did not correlate with the fat- $\%$ of the samples. It was probably due to changes of the colostrum induced by the treatment, which caused a blocking effect on the wells in the same way as the antibodies. Similar findings have been reported earlier (Bouwkamp et al. 1993, Levonen et al. 1996). The full spoilage of the samples in our study did, however, not alter the test results, possibly due to the centrifugation of the samples executed before the final analysis. The centrifugation probably eliminated any newly-formed substances (coagulations, bacterial mass, etc.) as also indicated by the centrifugation tests performed (Table 3). As a conclusion, a possible misstorage of colostrum samples is not a major problem when using the ELISA. However, a good sampling practice, when not using preserving additives, assumes a clean collection followed by a rapid refrigeration and freezing of the colostrum samples.

In a regular surveillance, a test should detect a recent infection as early as possible. Several authors have described risk factors for the reinfection of a herd indicating the importance of airborne transmission of $M$. hyopneumoniae between herds (Goodwin 1985, Thomsen et al. 1992, Stärk et al. 1992). Units with the highest airflow have increased risk of introducing aerosols containing the infectious agent, that is, the dry sow unit in farrowing herds and the finishing unit in farrowing-to-finishing herds (Laube et al. 1996). Furthermore, antibodies to $M$. hyopneumoniae have been detected in colostrum samples even weeks before the clinical outbreak of an acute disease (Sørensen et al. 1993, Levonen 1994a). That happened also in the elite breeding herd $\mathrm{X}$ in our study (data not shown). Hence, if colostrum samples were analysed frequently, e.g. monthly, they would probably be sensitive samples to detect also a recent infection.

\section{Acknowledgements}

This study was supported by the Finnish Veterinary Foundation. The authors thank the breeding herds that cooperated in this study, as well as the laboratory stuff. The authors also thank Mari Heinonen for providing information of the LSO-2000 quality chain, as well as Per Wallgren and Anna-Maija Virtala for critical reading of this paper and for excellent comments.

\section{References}

Anonymous: Agrifacts about Finland 1997a. Finfood. Vantaa, Finland.

Anonymous: Sikaloiden vapaaehtoinen terveysvalvontaohjelma. (A health control programme for breeding herds.) D 85, 30.7. 1997b. Finnish Ministry of Agriculture and Forestry. Veterinary and Food Department. Helsinki, Finland.

Anonymous: Animal diseases in Finland in 1997. Finnish Ministry of Agriculture and Forestry. Veterinary and Food Department. Helsinki, Finland. 1998.

Armstrong CH, Freeman MJ, Sands-Freeman L, Lopez-Osuna M, Young T, Runnels LJ: Comparison of the Enzyme-linked Immunosorbent Assay and the Indirect Hemagglutination and Complement Fixation Tests for Detecting Antibodies to Mycoplasma hyopneumoniae. Can. J. Comp. Med. 1983, 47, 464-470.

Bereiter M, Young TF, Joo H, Ross RF: Evaluation of the ELISA and comparison to the complement fixation test and radial immunodiffusion enzyme assay for detection of antibodies against $\mathrm{Myco}$ plasma hyopneumoniae in swine serum. Vet.Microb. 1990, 25, 177-192.

Bourne FJ, Curtis J: The transfer of immunoglobins IgG, IgA and IgM from serum to colostrum and milk in the sow. Immunology 1973, 24, 157-162.

Bouwkamp FT, Stegeman JA, Kimman TG: Use of colostrum to detect antibodies against glycoprotein I of Aujeszky's disease virus. Vet.Rec.1993, 133, 591-593.

Cannon RM, Roe RT: Livestock disease surveys: A field manual for veterinarians. Australian Bureau of Animal Health, Department of Primary Industry, Canberra, 1982, 14-17. 
Casella $G$, Berger $R L$ : Statistical inference. Wadsworth \& Brooks/Cole, Pacific Grove, California 1990, 90-92 and 444-445.

Christensen G, Sørensen V, Mousing J: Diseases of the respiratory system. In: Leman et al. (ed.): Diseases of swine. Iowa State University Press, Ames 1999, 913-940.

Eberli A: Evaluation eines ELISA zum Nachweis von Antikörpern gegen Mycoplasma hyopneumoniae im Blut und in der Milch von Schweinen. (Evaluation of an ELISA for the detection of antibodies to Mycoplasma hyopneumoniae in serum and colostrum of swine). Thesis. Universität Zürich, $1987.48 \mathrm{pp}$.

Goodwin RFW: Apparent reinfection of enzooticpneumonia-free pig herds: Search for possible causes. Vet.Rec. 1985, 116, 690-694.

Klobasa F, Butler JE, Werhahn E, Habe F: Maternalneonatal immunoregulation in swine. II. Influence of multiparity on de novo immunoglobulin synthesis by piglets. Vet.Immun. and Immunopath. 1986, 11, 149-159.

Klobasa F, Butler JE: Absolute and relative concentrations of immunoglobulins G, M and A, and albumin in the lacteal secretion of sows of different lactation numbers. Am.J.Vet.Res. 1987, 48, 176182.

Laube P, Stärk KDC, Keller H: A simulation of the eradication of enzootic pneumonia (EP) in a test region using a geographic information system (GIS). Proceedings of the 14th IPVS congress, Bologna, Italy, July 7-10, 1996. p. 536.

Levonen $K$. Detection of enzootic pneumonia in pig herds using an enzymelinked immunosorbent assay in sow colostrum. Res.Vet.Sci. 1994a, 56, 111-113.

Levonen K, Veijalainen P, Seppänen J: Actinobacillus pleuropneumoniae serotype- 2 antibodies in sow colostrum in Finnish pig-health-scheme herds. J.Vet.Med. B. 1994b, 41, 567-573.

Levonen K, Frandsen PL, Seppänen J, Veijalainen P: Detection of toxigenic Pasteurella multocida infections in swine herds by assaying antibodies in sow colostrum. J.Vet.Diagn.Invest. 1996, 8, 455459.

Martin SW, Meek AH, Willeberg P: Veterinary Epidemiology. Principles and methods. Iowa State University Press, Ames 1987, 45.

Martin SW, Shoukri M, Thorburn MA: Evaluating the health status of herds based on tests applied to individuals. Prev.Vet. Med. 1992, 14, 33-43.

Morris CR, Gardner IA, Hietala SK, Carpenter TE,
Anderson RJ, Parker KM: Persistence of passively acquired antibodies to Mycoplasma hyopneumoniae in a swine herd. Prev.Vet.Med. 1994, 21, 29-41.

Rautiainen E, Hautala M, Saranpää T, Virtala A-M: A comparative study of feeder pig units using dry or liquid feeding in the western part of Finland. Part 1: The mortality rate, the causes of death and the gastric ulceration. Suomen Eläinlääkäril. 1991, 97, 284-296. (English abstract).

Rautiainen $E$, Nyberg $M$, Levonen $K$ : The use of sow colostrum samples for regular herd health control of Mycoplasma hyopneumoniae infection. Proceedings of the 14th IPVS congress, Bologna, Italy, July 7-10, 1996. p. 219.

Rautiainen E: The prevalence of Mycoplasma hyopneumoniae in pig herds in

Western Finland based on the demonstration of antibodies in colostrum by ELISA. Acta vet. scand. 1998, 39, 325-330.

Ross RF: Mycoplasmal diseases. In: Leman et al. (ed.): Diseases of swine. Iowa State University Press, Ames 1999, 495-509.

Stärk KDC, Keller H, Eggenberger E: Risk factors for the reinfection of specific pathogen-free pig breeding herds with enzootic pneumonia. Vet. Rec. 1992, 131, 532-535.

Sørensen $V$, Barfod $K$, Feld NC: Evaluation of a monoclonal blocking ELISA and

IHA for antibodies to Mycoplasma hyopneumoniae in SPF-pig herds. Vet.Rec. 1992, 130, 488490.

Sørensen V, Barfod K, Feld NC, Vraa-Andersen L: Application of enzyme-linked immunosorbent assay for the surveillance of Mycoplasma hyopneumoniae infection in pigs. Rev. Sci. Tech. Off. Int. Epiz. 1993, 12, 593-604.

Sørensen $V$, Ahrens $P$, Barfod K, Feenstra AA, Feld NC, Friis NF, Bille-Hansen V, Jensen NE, Pedersen MW: Mycoplasma hyopneumoniae infection in pigs: Duration of the disease and evaluation of four diagnostic assays. Vet.Microb. 1997, 54, 23 34.

Thomsen BL, Jorsal SE, Andersen S, Willeberg P: The Cox regression model applied to risk factor analysis of infections in the breeding and multiplying herds in the Danish SPF system. Prev. Vet.Med. 1992, 12, 287-297.

Tuovinen VK, Levonen KH, Gröhn YT, Straw BE: The prevalence of some economically important swine diseases in farrowing units in Southwestern Finland. Prev.Vet.Med. 1994, 19, 85-100. 
Tuovinen VK, Heinonen ML: Diminishing the need of antibiotics in pork production. Proceedings of the 9th International Congress in Animal Hygiene, Helsinki, Finland, August 17-21, 1997. pp. 262-265.

Wallgren P, Bölske G, Gustafsson S, Mattsson S, Fossum C: Humoral immune response to Mycoplasma hyopneumoniae in sows and offsprings following an outbreak of mycoplasmosis. Vet. Microb. 1998, 60, 193-205.

Yagihashi T, Kazama S, Tajima M: Seroepidemiology of mycoplasmal pneumonia of swine in Japan as surveyd by an enzyme-linked immunosorbent assay. Vet.Microb. 1993, 34, 155-166.

Zimmermann $W$, Tschudi P, Nicolet J: ELISA-Serologie in Blut und Kolostralmilch: eine Möglichkeit zur Überwachung der enzootischen Pneumoniae (EP) in Schweine-Beständen. (ELISA serology on milk and serum: a possibility to a herd health control of enzootic pneumonia in swine herds.) Schweiz. Arch.Tierheilk. 1986, 128, 299-306.

Zimmermann $W$, Odermatt $W$, Tshudi $P$ : Enzootische pneumoniae (EP): Die Teilsanierung EP-reinfizierter Schweinezuchtbetribe als alternative zur Totalsanierung. (Swine enzootic pneumonia: Partial depopulation as an alternative to total depopulation in eradication of the infection.) Schweiz.Arch.Tierheilk. 1989, 131, 179-191.

\author{
Sammanfattning \\ Analys av antikroppar gentemot Mycoplasma \\ hyopneumoniae - er metod att dokumentera infek- \\ tionsfrihet
}

I en kartläggning i Finland år 1995 analyserades 14 919 råmjölksprov från 530 besättningar för antikroppar mot Mycoplasma hyopneumoniae (M. hyopneumoniae). En monoklonal blocking-ELISA användes. I småbesättningarna analyserades prov från varje sugga. I de stora besättningarna analyserades 30 prov. Alla besättningarna var med $\mathrm{i}$ något hälsoövervakningsprogram. Antikroppar mot M. hyopneumoniae konstaterades i 274 prov (1.8\%) och i 42 besättningar (7.9\%). Medianprevalensen av suggor med antikroppar i seropositiva besättningar var $28.2 \%$ (variation, $2.7 \%-100 \%$ ). Enligt uppföljning i år 1996 var alla besättningarna, som var seronegativa i 1995, faktiskt infektionsfria avseende M. hyopneumoniae. I akut infekterade besättningarna var prov som hade mjölkats tidigare än 2 timmar efter grisningen, 3 gånger oftare seropositiva än prov som hade mjölkats 2-12 timmar efter grisningen (odds ratio, 3.0; 95\% konfidens intervall 1.4-6.6). Upprepad frysning eller förskämning av råmjölksprov påverkade inte betydligt resultaten av ELISA testen. Efter en lyckad sanering påvisades antikroppar mot $M$. hyopneumoniae upp till 3 år efter saneringen bland suggor som var födda före saneringen. Sammanfattningsvis; råmjölksprov kan effektivt användas för kartläggning av suggbesättningar avseende $M$. hyopneumoniae infektion. Råmjölksprovtagning förefaller användbar också för regelbunden kontroll för nyinfektioner.

(Received February 1, 1999; accepted January 4, 2000).

Reprints may be obtained from: E. Rautiainen, EELA, P.O. Box 198, FIN-60101 Seinajok, Finland. E-mail: Eero.Rautiainen@EELA.FI, tel: +358-6-4218 102, fax: +358-6-4218 180. 